\title{
Impairment of Esophageal Clearance Following Swallowing in Upright Position
}

National Cancer Institute

\section{Source}

National Cancer Institute. Impairment of Esophageal Clearance Following Swallowing in Upright Position. NCI Thesaurus. Code C127343.

An observation of an individual's esophageal clearance after swallowing in an upright position. 